\title{
Pengembangan Aplikasi Untuk Desain Perhitungan Sistem Proteksi Katodik Arus Paksa Anjungan Lepas Pantai
}

\author{
A. Wiryawan* dan P. T. Iswanto \\ Departemen Teknik Mesin dan Industri, Fakultas Teknik, Universitas Gadjah Mada. \\ Jl. Grafika No. 2, Kompleks UGM, Yogyakarta 55281, Indonesia \\ E-mail:*andi.mail2015@gmail.com
}

\begin{abstract}
Abstrak
Beberapa aplikasi desain telah dibuat oleh peneliti sebelumnya untuk mendesain sistem proteksi katodik arus paksa pada pipe penyalur dan tangki, serta sistem proteksi katodik anoda korban pada pipa dan anjungan lepas pantai. Namun sepengetahuan penulis belum ada penelitian mengenai pembuatan aplikasi desain sistem proteksi katodik arus paksa anjungan lepas pantai. Penelitian ini bertujuan untuk membuat aplikasi desain sistem proteksi katodik arus paksa pada anjungan lepas pantai.

Aplikasi dibuat dengan mengaplikasikan beberapa perhitungan dari beberapa literatur dengan pendekatan empiris. Dari hasil output aplikasi tersebut kemudian dibandingkan dengan nilai atenuasimya untuk mengkonfirmasi kecukupan arus. Kemudian analisa keekonomisan dapat dilakukan dengan memvariasikan parameter umur layan, tipe cat yang digunakan, serta luas permukaan dicat. Desain struktur dan kondisi parameter lingkungan anjungan lepas pantai "V" di PT. XYZ digunakan sebagai objek penelitian.

Output yang dihasilkan dari aplikasi hasil penelitian ini antara lain kebutuhan arus DC, jumlah anoda, tegangan \& arus DC, dan kapasitas daya transformer/rectifier. Didapatkan bahwa pada umur layan 15 tahun membutuhkan 2 buah anoda, sedangkan dari atenuasi didapat bahwa jumlah anoda mencukupi untuk menjangkau seluruh bagian struktur. Aplikasi desain berhasil dibuat dengan merujuk pada beberapa literatur dari peneliti-peneliti sebelumnya. Selain dari sisi teknis, simulasi keekonomisan juga dapat dilakukan menggunakan aplikasi tersebut.
\end{abstract}

Kata kunci: anjungan lepas pantai, proteksi katodik, arus paksa, atenuasi.

\begin{abstract}
Several applications design have been made by previous researchers to design impressed current cathodic protection (ICCP) systems on pipelines and tanks, and sacrificial anodes cathodic protection systems for pipelines and offshore platforms. However, to the knowledge of the author, there are no study on the design application for ICCP system for offshore platforms. This study aims to create a design application for ICCP system for offshore platforms.

Application is made by applying formula from various literature with empirical approach. The output of the application is then compared with the attenuation value to confirm current is sufficient. Economic analysis can be done by varying the parameters of service life, type of paint, and painted surface area. Structural design and environmental parameters of the "V" offshore platform at PT. XYZ is use as research object.

Output from this application includes DC current requirements, number of anodes, DC voltages \& currents, and transformer/rectifier power capacity. It was found that with service
\end{abstract}


life of 15 years requires 2 pieces of anodes, while from the attenuation it was found to be sufficient to protect all submerged parts of the structure. The design application has been successfully made by referring to some literature from previous researchers. Apart from the technical side, economic simulations also can be carried out using the application.

Keywords: offshore platform, cathodic protection, impressed current, attenuation.

\section{PENDAHULUAN}

Proteksi katodik adalah salah satu metode penanggulangan korosi yang umum digunakan untuk melindungi struktur baja yang terendam di lingkungan laut. Metode ini dilakukan dengan cara menghubungkan struktur baja yang akan dilindungi dengan metal lain yang memiliki keelektronegatifan lebih rendah atau dengan mengalirkan arus listrik melalui anoda eksternal. Dengan begitu nilai potensial struktur tersebut akan turun dibawah nilai potensial kriteria proteksi yaitu sebesar $-800 \mathrm{mV}$ vs $\mathrm{Ag} / \mathrm{AgCl}$ (Bardal, 2004). Umumnya desain proteksi katodik di jaman modern dibuat berdasarkan recommended practice atau standar internasional, pendekatan empiris, dan panduan dari beberapa pengalaman praktis sebelumnya (Veronelli, 2012). Parameter lain seperti jumlah anoda dan penempatan anoda yang memiliki banyak parameter yang berpengaruh masih bergantung kepada pengetahuan dan pengalaman tenaga ahli pembuat desain sistem proteksi katodik tersebut (Lan et al., 2011).

Studi ini bertujuan untuk membuat sebuah aplikasi baku yang dapat digunakan untuk memudahkan dalam membuat desain perhitungan sistem proteksi katodik arus paksa untuk struktur anjungan lepas pantai dan melakukan simulasi keekonomisan berdasarkan parameter pemakaian kombinasi sistem proteksi katodik dan cat pelindung. Desain struktur dan kondisi parameter lingkungan pada anjungan lepas pantai "V" di PT. XYZ akan digunakan sebagai objek penelitian. Dengan adanya aplikasi yang baku, diharapkan proses desain dapat berjalan lebih efisien dan dapat mengetahui desain yang paling ekonomis.

Beberapa peneliti seperti Dewald dkk dan Veronelli melakukan penelitian mengenai pembuatan aplikasi desain proteksi atodik. Dewald dkk membuat sebuah aplikasi (framework) perhitungan sistem proteksi katodik arus paksa yang kemudian diaplikasikan untuk objek tangki dan pipa penyalur yang terkubur dalam tanah. Dalam aplikasinya ada beberapa metode khusus yang diaplikasikan, antara lain untuk kapasitas keluaran arus anoda mengacu kepada rekomendasi manufaktur sesuai dengan umur layannya, untuk tahanan sirkuit beliau mengacu kepada formula Dwight. Veronelli membuat aplikasi berbasis Visual Basic for Application (VBA) menggunakan excel untuk membuat aplikasi desain proteksi katodik anoda korban. Beliau membuat beberapa modul untuk membuat desain proteksi katodik pada antara lain pipa penyalur bawah tanah dan anjungan lepas pantai. Aplikasi tersebut memakai formula Dwight untuk menentukan tahanan anoda, serta memperhitungkan nilai kebutuhan maksimum anoda pada fase initial sampai final. Dari aplikasi tersebut kemudian dilakukan optimasi untuk keekonomisan dimensi dan jumlah anoda korban. Hal penting yang harus diperhatikan dalam penempatan anoda yaitu untuk zona percikan anoda diletakkan di batas bawah dari pasang surut air laut, sedangkan untuk zona terkubur anoda diletakkan didekat dengan permukaan tanah bawah laut tersebut untuk menjamin sebaran arus menjangkau keseluruhan bagian struktur.

Pada penelitian ini output dari aplikasi akan berupa nilai kebutuhan arus, tegangan, serta kapasitas transformer/ rectifier yang dibutuhkan pada sistem proteksi katodik arus paksa tersebut. Nilai atenuasi atau sebaran arus juga dihitung untuk mengetahui distribusi sebaran arus dan mengkonfirmasi kecukupan jumlah anoda. Analisa keekonomisan desain kemudian dilakukan 
A. Wiryawan dan P. T. Iswanto / Journal of Mechanical Design and Testing 2(1), (2020), 11-20

dengan menggunakan aplikasi tersebut dengan memvariasikan parameter umur layan, tipe cat yang digunakan, serta luas permukaan dicat.

\section{METODE PENELITIAN}

Aplikasi perhitungan sistem proteksi katodik arus paksa untuk anjungan lepas pantai dibuat menggunakan piranti lunak Microsoft Excel dan Matlab yang umum digunakan, sehingga mahasiswa atau industri kecil juga dapat menggunakannya.

Penelitian dimulai dengan mengumpulkan informasi mengenai beberapa parameter penting yang akan dijadikan input variabel dalam perhitungan, seperti data lingkungan, dimensi struktur dan anoda, tahanan kabel, data peralatan listrik, dan lainnya. Dari data parameter tersebut kemudian perlu ditentukan kriteria proteksi dari sistem proteksi katodik tersebut. Pada penelitian ini, salah satu anjungan lepas pantai di Kalimantan Timur digunakan sebagai obyek penelitian. Ilustrasi bentuk anjungan dan posisi geografis ditunjukkan di Gambar 1.
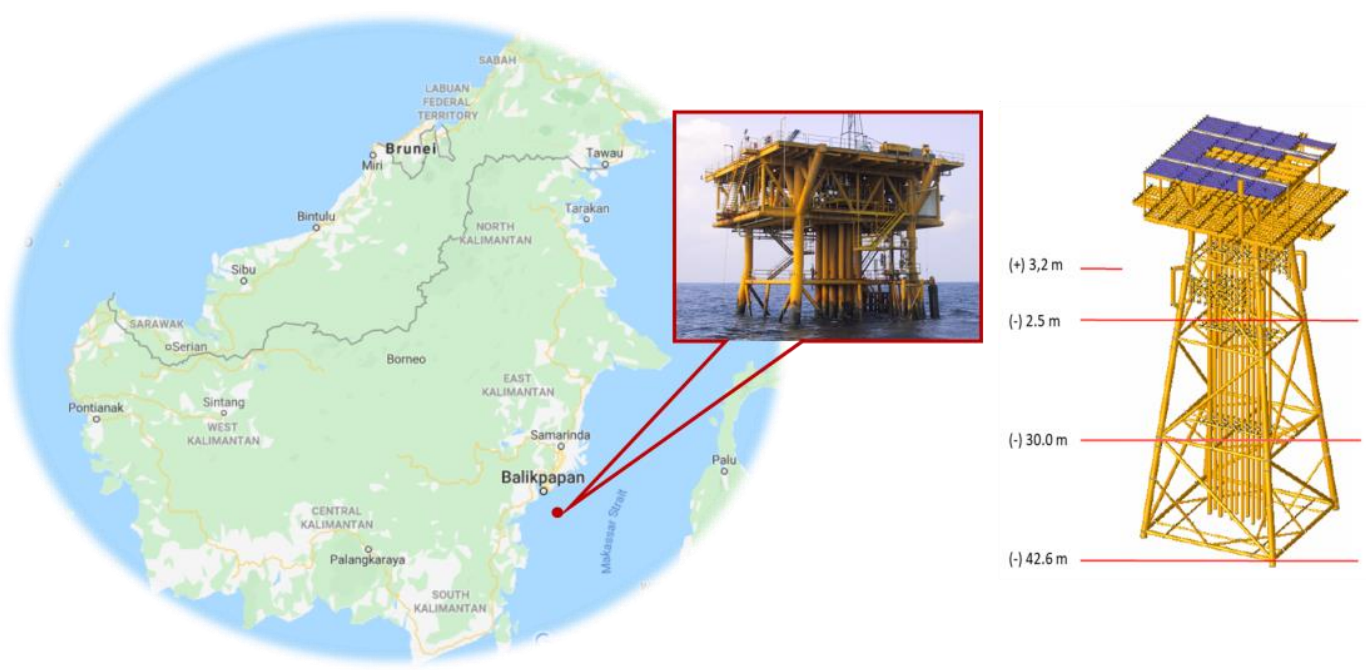

Gambar 1. Ilustrasi Bentuk dan Letak Geografis Anjungan "V” PT. XYZ 
A. Wiryawan dan P. T. Iswanto / Journal of Mechanical Design and Testing 2(1), (2020), 11-20

Pada Tabel 1 berikut ini merupakan data parameter yang digunakan pada penelitian ini.

Tabel 1. Parameter Desain

\begin{tabular}{|c|c|c|c|}
\hline \multicolumn{2}{|l|}{ Parameter Desain } & \multicolumn{2}{|l|}{ Parameter Anoda } \\
\hline Umur Layan & $10,20,30,40$ tahun & Dimensi Anoda & \\
\hline \multicolumn{2}{|l|}{ Parameter Lingkungan } & Diameter Anoda & $15.875 \mathrm{~mm}$ \\
\hline Kedalaman Air Laut & 42.67 meter dibawah MSL & Panjang Anoda & $1,219 \mathrm{~mm}$ \\
\hline Temperatur Air Laut & $20^{\circ} \mathrm{C}$ & Jarak Antar Anoda (anoda $>1$ ) & $1000 \mathrm{~mm}$ \\
\hline Tahanan Air Laut & $0.19 \Omega . \mathrm{m}$ & Rapat Arus Anoda (max) & $600 \mathrm{~mA} / \mathrm{m}^{2}$ \\
\hline \multicolumn{2}{|l|}{ Parameter Struktur } & \multicolumn{2}{|l|}{ Parameter Peralatan Listrik } \\
\hline MaterialStruktur & ASTM A-36 & Tahanan Kabel \#1 & $0.001075 \mathrm{ohm} / \mathrm{m}$ \\
\hline Luas Area Struktur & $6050.48 \mathrm{~m}^{2}$ & Tahanan Kabel \#2 & $0.00033456 \mathrm{ohm} / \mathrm{m}$ \\
\hline Zona Percikan & $746.79 \mathrm{~m}^{2}$ & Sumber Listrik AC & 415 Volt/ 3Phase/ 50Hz, \\
\hline Zona Terendam & $3452.8 \mathrm{~m}^{2}$ & Transformer/Rectifier & DC output 150 Volt - 200 Ampere \\
\hline Zona Terkubur & $1850.89 \mathrm{~m}^{2}$ & & \\
\hline Tahanan Struktur & $0.00000018 \Omega . \mathrm{m}$ & & \\
\hline
\end{tabular}

Dari data yang didapatkan, kriteria proteksi yang digunakan adalah $-800 \mathrm{mV}$ terhadap elektroda acuan $\mathrm{Ag} / \mathrm{AgCl}$. Nilai proteksi tersebut sesuai dengan nilai yang disarankan di beberapa literatur (Bardal, 2004; Veronelli, 2012; Diedericks et al., 2019) dan standar internasional. Pada perhitungan selanjutnya, rumus yang dipakai banyak mengacu kepada standar internasional dan beberapa literatur. Standar internasional yang dipakai pada penelitian ini mengacu pada DNV, yang telah banyak diacu juga oleh peneliti lain dan divalidasi menggunakan eksperimen maupun pemodelan seperti yang dilakukan oleh Baete dkk, Stutzmann dan Meillier. Perhitungan desain spesifikasi sistem proteksi katodik arus paksa akan dibandingkan dengan perhitungan sebaran arus anoda atau atenuasi untuk mengkonfirmasi jumlah anoda yang diperlukan dengan kapasitas sebaran arusnya. Setelah hasil yang didapat sesuai, maka dapat dilanjutkan dengan melakukan perhitungan estimasi biaya. Perhitungan biaya dilakukan dengan memakai tiga variabel, yaitu umur layan, tipe cat yang digunakan, serta luas permukaan dicat. Dari hasil simulasi tersebut kemudian akan dibandingkan untuk menentukan kombinasi variabel yang paling optimum.

\subsection{Desain Perhitungan Sistem Proteksi Katodik Arus Paksa}

Desain empiris dari sistem Proteksi Katodik Arus Paksa akan dipaparkan pada bab ini. Formula perhitungan yang digunakan dalam penelitian ini berasal dari panduan standar internasional maupun literatur lainnya. Setelah data-data yang dibutuhkan terkumpul, langkah selanjutnya adalah menentukan kriteria proteksi seperti kebutuhan rapat arus dan faktor kerusakan cat. Pada penelitian ini data tersebut mengacu pada DNV, kebutuhan arus bergantung pada iklim, temperatur, dan kedalaman laut. Sedangkan faktor kerusakan cat bergantung pada umur layan, tipe cat, dan kedalaman laut pada struktur yang dicat. Nilai kebutuhan arus dirumuskan dengan persamaan (1) sebagai berikut:

$$
I_{t}=\left[\left(A \cdot \frac{i_{c} \cdot f_{C}}{1000}\right) \times\left(1+S_{f}\right)\right]
$$

Dimana, $I_{t}=$ kebutuhan arus $(A), A=$ luas permukaan struktur $\left(\mathrm{m}^{2}\right), \mathrm{i}_{\mathrm{c}}=$ rapat arus mengacu ke DNV $\left(\mathrm{mA} / \mathrm{m}^{2}\right), \mathrm{f}_{\mathrm{c}}=$ faktor kerusakan cat mengacu DNV $(\%), \mathrm{S}_{\mathrm{f}}=$ faktor 
keselamatan (\%). Selanjutnya dapat dihitung jumah anoda yang dibutuhkan. Karena anoda yang digunakan adalah anoda Ti-MMO, nilai arus output maksimum yang dihasilkan dari anoda tersebut dipengaruhi oleh umur layannya (Shreir et al., 1993). Kemudian baru dapat dihitung kapasitas keluaran arus masing-masing anoda dengan menggunakan persamaan berikut:

$$
I_{a n}=I_{d} \times A_{a n}
$$

Dimana $I_{a n}=$ kapasitas keluaran arus individual anoda (A), $I_{d}=$ kapasitas arus individual anoda $\left(\mathrm{A} / \mathrm{m}^{2}\right)$, dan $\mathrm{A}_{\mathrm{an}}=$ luas permukaan anoda $\left(\mathrm{m}^{2}\right)$. Kemudian jumlah kebutuhan anoda dapat dihitung dari kebutuhan arus total dan kapasitas keluaran individu anoda.

Langkah selanjutnya adalah mencari kebutuhan arus dan tegangan DC untuk menentukan kapasitas transformer/rectifier yang dibutuhkan. Pertama-tama perlu diketahui tahanan sirkuit dari sistem proteksi katodik tersebut. Tahanan pada sirkuit tersebut dapat diilustrasikan seperti yang ditunjukkan pada Gambar 2 berikut.

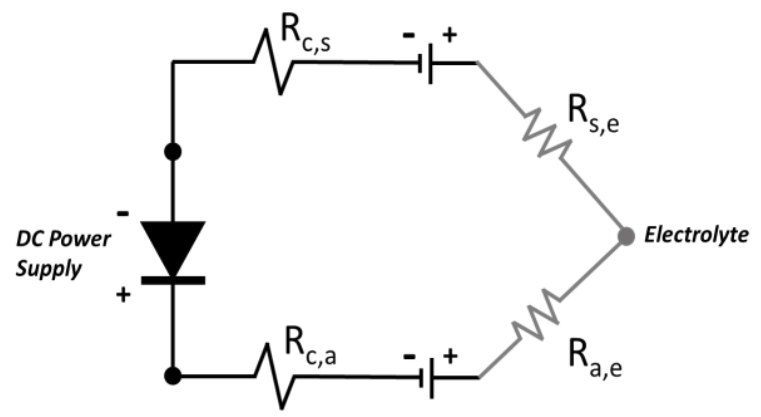

Gambar 2. Ilustrasi tahanan sirkuit sistem proteksi katodik arus paksa pada struktur anjungan lepas pantai

Tahanan total pada sirkuit dapat dirumuskan sebagai berikut:

$$
R_{\text {Total }}=R_{c, a}+R_{c, s}+R_{a, e}
$$

Dimana, $\mathrm{R}_{\text {total }}=$ tahanan sirkuit total, $\mathrm{R}_{\mathrm{c}, \mathrm{a}}=$ tahanan kabel pada bagian anoda, $\mathrm{R}_{\mathrm{c}, \mathrm{s}}=$ tahanan kabel pada bagian struktur, $\mathrm{R}_{\mathrm{a}, \mathrm{e}}=$ tahanan anoda terhadap elektrolit, dan $\mathrm{R}_{\mathrm{s}, \mathrm{e}}=$ tahanan struktur terhadap elektrolit. Nilai $\mathrm{R}_{\mathrm{s}, \mathrm{e}}$ dapat diabaikan karena nilainya yang sangat kecil dibandingkan dengan tahanan lainnya (Bahadori, 2014).

Setelah tahanan sirkuit didapatkan, maka jumlah arus dan tegangan DC yang dibutuhkan dapat dihitung dengan menggunakan rumus berikut:

Tegangan DC:

Arus DC:

$$
E_{T}=\left\{I_{t} \times R_{T} \times\left(1+S_{f}\right)\right\}+B_{e m f}
$$

$$
I_{A C}=\frac{E_{T} I_{t}}{E_{A C} \cdot \eta \sqrt{3 \cdot \cos \varnothing}}
$$

Daya transformer/rectifier:

$$
P_{A C}=\sqrt{3} \times I_{A C} \times E_{A C}
$$


Dimana $\mathrm{E}_{\mathrm{AC}}=$ input tegangan $\mathrm{AC}(415$ Volt $), \mathrm{E}_{\mathrm{T}}=$ output tegangan $\mathrm{DC}$ yang dibutuhkan (Volt), $\mathrm{B}_{\mathrm{emf}}=$ Back Electromotive Force (2 Volt), $\eta=$ Transformer Rectifier Efficiency (70\%), $\operatorname{Cos} \varnothing=$ Sudut fase listrik AC $(0,85), \mathrm{I}_{\mathrm{AC}} \quad=$ Input Arus AC (A).

\subsection{Perhitungan Jangkauan Atenuasi/Distribusi Arus Proteksi Katodik}

Ketika arus pelindung mengalir ke struktur, nilai potensial dan jumlah arus listrik akan berkurang seiring dengan bertambahnya jarak dari sumber arus atau anoda, seperti ilustrasi pada Gambar 3. Fenomena ini disebut dengan atenuasi, nilai laju penurunan arus dan potensial bergantung pada tahanan struktur, konduktivitas coating, polarisasi, jarak, dan adanya insulasi pada area sekitar sistem tersebut (Smith, 1992).

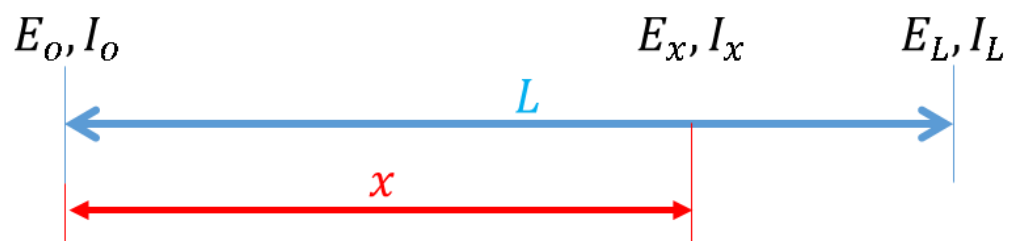

Gambar 3. Ilustrasi Hubungan Antara Jarak Dengan Nilai Arus Dan Potensial

Jangkauan atenuasi pada sistem proteksi katodik dapat dirumuskan sebagai berikut:

$$
\begin{aligned}
& E_{x}=E_{a} e^{(-\alpha X)} \text { Atau } \\
& X=\frac{\operatorname{arccosh}\left(\frac{E_{a}}{E_{x}}\right)}{\alpha}
\end{aligned}
$$

Dimana $X=$ jangkauan arus atenuasi $(\mathrm{m}), \mathrm{E}_{\mathrm{a}}=$ potensial struktur dekat anode $(-550 \mathrm{mV}$ $\mathrm{s} / \mathrm{d}-1200 \mathrm{mV}), \mathrm{E}_{\mathrm{x}}=$ potensial struktur pada jarak $\mathrm{x}(-550 \mathrm{mV} \mathrm{s} / \mathrm{d}-850 \mathrm{mV})$. Nilai konstanta atenuasi $(\alpha)$ sangat berpengaruh dalam memprediksi besaran penyusutan yang terjadi sepanjang jarak terhadap anoda. Semakin kecil resistansi pada struktur termasuk cat pelindung, semakin besar nilai konstanta atenuasinya. Nilai konstanta atenuasi $(\alpha)$ dapat dirumuskan sebagai berikut:

$$
\alpha=\sqrt{r \cdot g}
$$

Dimana: $\mathrm{r}=$ tahanan struktur $(\mathrm{ohm} / \mathrm{m}), \mathrm{g}=$ konduktivitas cat $(\mathrm{S} / \mathrm{m})$.

\subsection{Optimasi Desain}

Menggunakan aplikasi perhitungan tersebut, langkah selanjutnya adalah melakukan simulasi desain yang paling optimal pada anjungan lepas pantai "V" milik PT. XYZ yang menjadi objek dalam penelitian. Variabel yang akan dipakai untuk mencari nilai optimum keekonomisan dari desain proteksi katodik ini yaitu: Jenis cat, berdasarkan $\mathrm{DNV}^{[5]}$ ada 3 jenis tipe kategori yaitu Type-1: satu lapis cat epoxy, total min. DFT $20 \mu \mathrm{m}$, Type-2: satu atau lebih lapis cat marine (berbasis epoxy, polyurethane, atau vynil), total min. DFT $250 \mu \mathrm{m}$, Type-3: dua atau lebih lapis cat marine (berbasis epoxy, polyurethane, atau vynil), total min. DFT $350 \mu \mathrm{m}$. Luas permukaan penggunaan cat, dibagi menjadi 3 jenis yaitu Full-coat: yaitu seluruh permukaan struktur dicat, Splash zone: yaitu hanya area di zona percikan yang dicat, Uncoated: yaitu tidak menggunakan cat. Umur layan, dibagi menjadi 3 jenis yaitu 5 tahun, 10 tahun, dan 15 tahun. 
A. Wiryawan dan P. T. Iswanto / Journal of Mechanical Design and Testing 2(1), (2020), 11-20

\section{HASIL DAN PEMBAHASAN}

Aplikasi untuk perhitungan telah dibuat menggunakan Microsoft Excel dan Matlab sehingga dapat dijalankan menggunakan komputer yang umum. Gambar 4a dan Gambar 4b menunjukkan skema perhitungan tersebut. Total ada 19 variabel parameter input yang dibutuhkan.

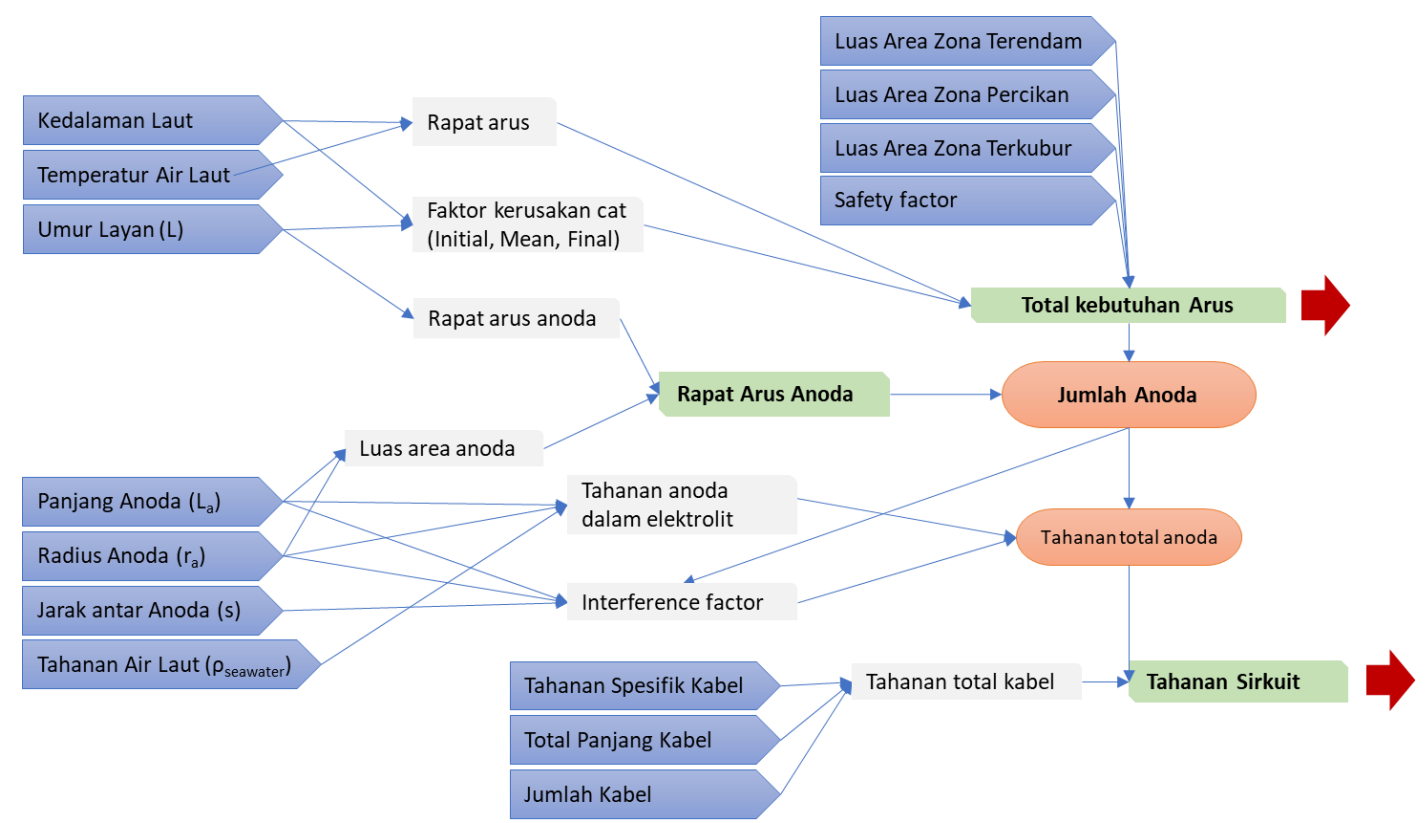

Gambar 4a.. Skema Perhitungan Aplikasi Desain Sistem Proteksi Katodik Arus Paksa Struktur Anjungan Lepas Pantai (1 dari 2)

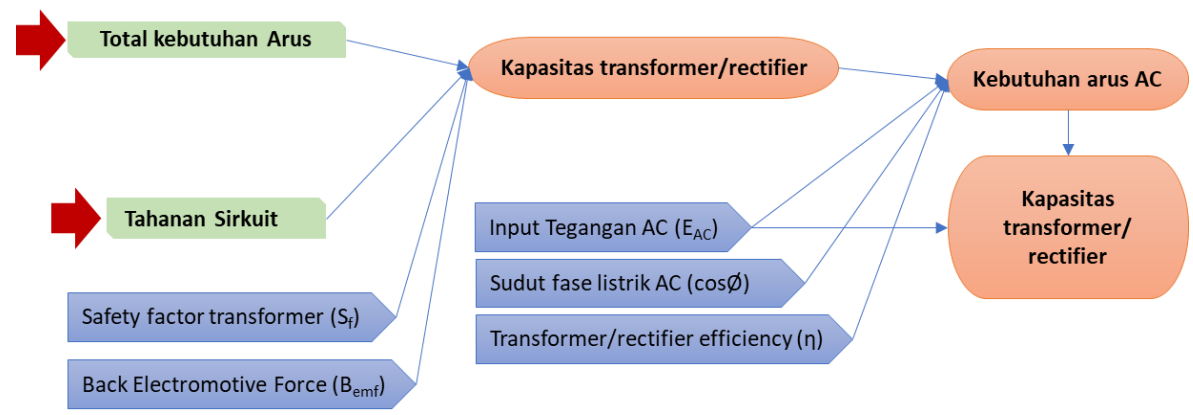

Gambar 4b. Skema Perhitungan Aplikasi Desain Sistem Proteksi Katodik Arus Paksa Struktur Anjungan Lepas Pantai (2 dari 2)

Hasil perhitungan untuk data kebutuhan arus dan jumlah anoda dapat dilihat dari Gambar 5 dan Gambar 6, hasil perhitungan tersebut untuk anjungan "V" dengan menggunakan cat tipe-2 pada keseluruhan struktur. Apabila dilihat dari kebutuhan arus pada periode initial, mean, dan final dari Gambar 5 dapat dilihat bahwa kebutuhan arus mengalami perubahan di setiap periode. Nilai initial, mean, dan final dibuat untuk mengasumsikan perubahan kebutuhan arus yang berubah seiring waktu, karena adanya fenomena penumpukan deposit kalsium, biota laut, 
maupun proses polarisasi Pada struktur tanpa cat pelindung, kebutuhan arus pada masa awal lebih besar dibandingkan dengan masa pertengahan, dikarenakan oleh adanya scale deposit yang akan terbentuk selama masa proteksi berlangsung. Sedangkan pada periode final kebutuhan arus lebih tinggi dikarenakan pada masa tersebut diprediksi scale deposit dan marine growth telah rusak dan perlu dipolarisasi kembali untuk mengembalikan lapisan tersebut. Pada Gambar 5 dan Gambar 6 dapat dilihat bahwa nilai kebutuhan arus dan jumlah anode meningkat seiring bertambahnya umur layan. Hal ini disebabkan oleh faktor kerusakan cat, yang dipengaruhi oleh fungsi waktu yang menggambarkan bahwa cat akan rusak seiring bertambahnya umur struktur tersebut.

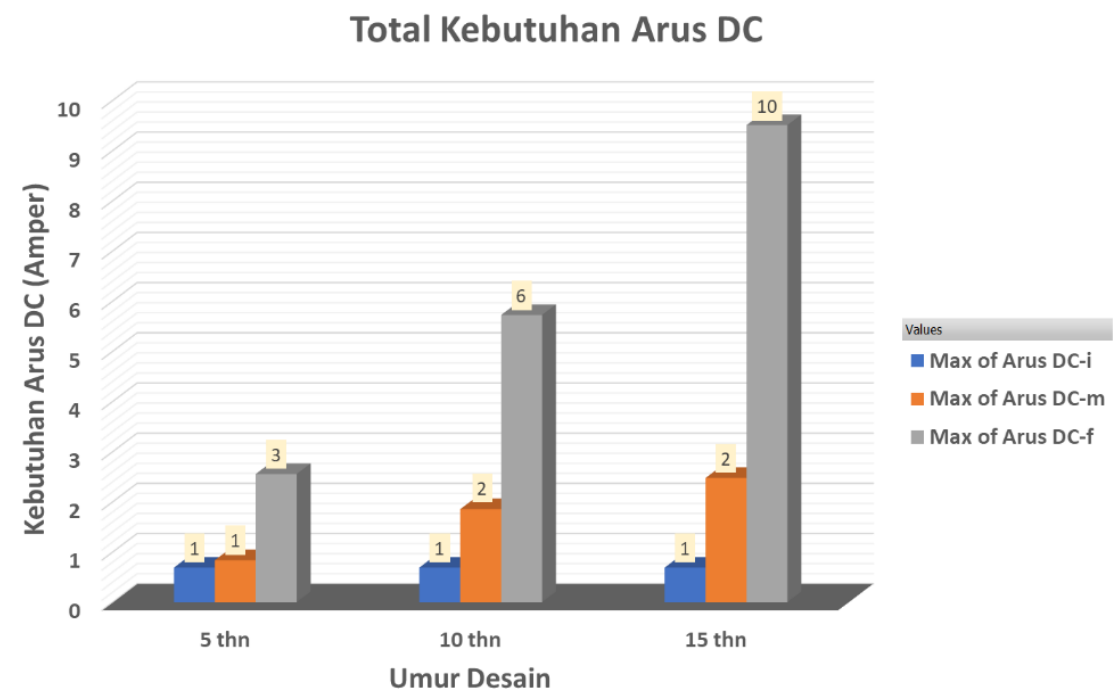

Gambar 5. Grafik Hasil Perhitungan Kebutuhan Arus DC Dengan Beberapa Variasi Umur Desain

Total Kebutuhan Anoda

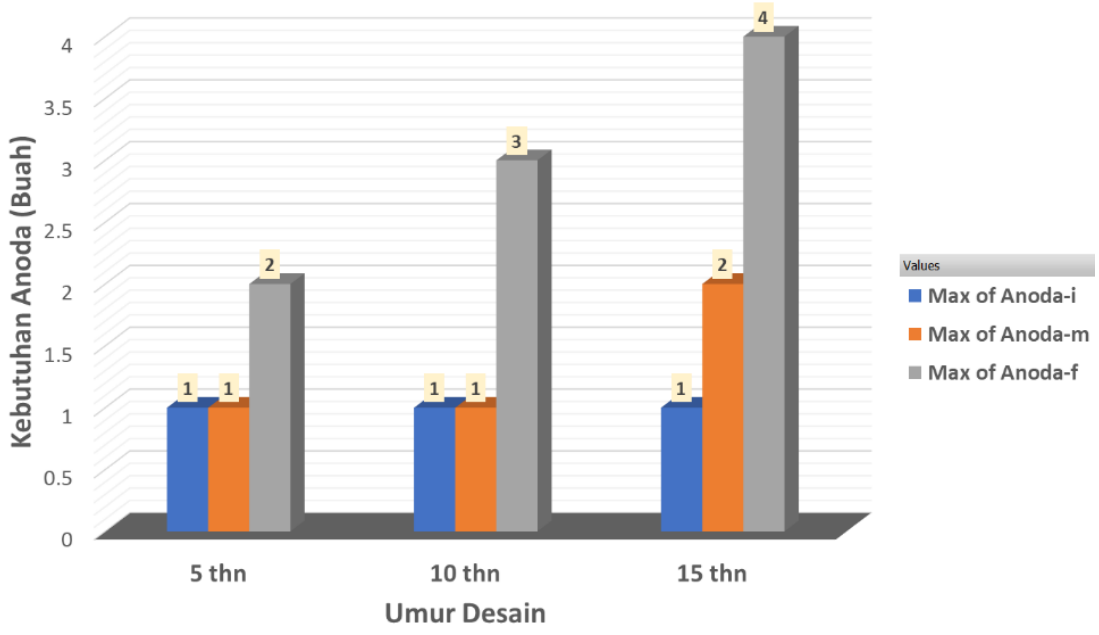

Gambar 6. Grafik Hasil Perhitungan Kebutuhan Anoda Dengan Beberapa Variasi Umur Desain 
Nilai atenuasi dipengaruhi oleh nilai tahanan struktur dan tahanan cat pelindung, sehingga dalam penelitian ini hanya dipengaruhi oleh tipe cat. Hasil perhitungan nilai atenuasi menunjukkan bahwa pada struktur tanpa cat, jangkauan arus adalah74 meter yang berarti dapat menjangkau keseluruhan struktur anjungan "V" tersebut.

Setelah aplikasi dibuat, dilakukan optimasi sesuai dengan variabel yang telah dijelaskan pada bagian 2.3 sebelumnya. Hasil dari simulasi keekonomisan tersebut dapat dilihat pada grafik Gambar 7 berikut:

\section{Perkiraan Biaya}

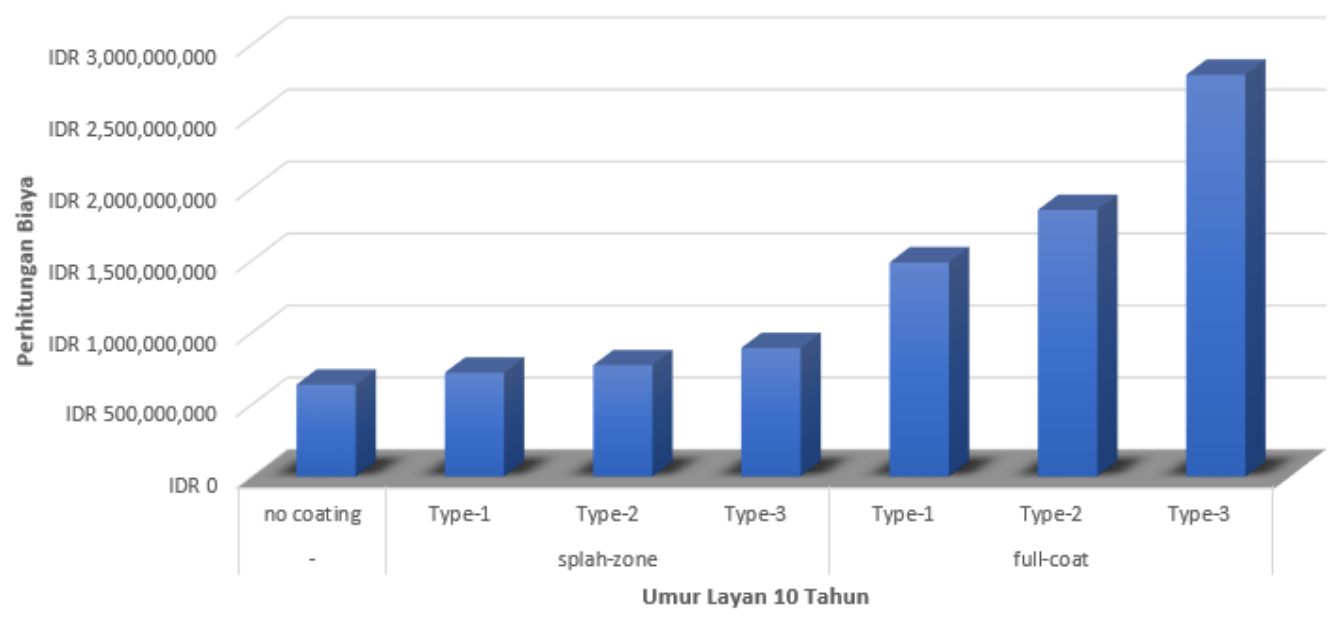

Gambar 7. Grafik Hasil Simulasi Perkiraan Biaya

Pada Gambar 7 sebagai contoh simulasi perkiraan biaya pada desain dengan variasi area permukaan yang dicat dan tipe cat yang digunakan pada umur layan 10 tahun. Dari hasil simulasi biaya, didapat bahwa untuk umur layan 10 tahun lebih ekonomis untuk tanpa menggunakan cat. Sedangkan pada umur layan diatas 30 tahun tahun, desain system proteksi katodik lebih ekonomis apabila menggunakan cat tipe II pada zona percikan (splash zone). Sedangkan cat pada keseluruhan struktur tidak ekonomis untuk dikombinasikan dengan system proteksi katodik, karena biaya aplikasi cat yang jauh lebih tinggi. Dilihat dari trend kebutuhan anoda, semakin panjang umur layan maka didapat semakin besar jumlah anoda yang dibutuhkan.

\section{KESIMPULAN}

Aplikasi sistem proteksi katodik telah dibuat dengan mengeluarkan output kebutuhan arus DC, jumlah anoda, tegangan \& arus DC, dan kapasitas daya transformer/rectifier. Aplikasi dapat melakukan simulasi perhitungan biaya dengan variabel umur layan, tipe cat yang digunakan, serta luas permukaan sehingga dapat menentukan desain yang paling optimum. Optimasi desain dapat dikembangkan lebih lanjut menggunakan aplikasi ini dengan melakukan variasi variabel lainnya, seperti jenis anoda, jenis rectifier/transformer, dan cat pelindung jenis yang lain. 


\section{DAFTAR PUSTAKA}

Bardal, E., 2004, Corrosion and Protection, Springer, Trondheim.

Veronelli, L. A., 2012, Empirical and Computer Aided Design of Cathodic Protection Systems, Paper presented at the Politecnico Di Milano.

Lan, Z., Wang, X., Hou, B., Wang, Z., Song, J., Chen, S., 2011, Simulation of sacrificial anode protection for steel platform using boundary element method, Analysis with Boundary element, hal 903-906.

Diedericks, D. E., Schoor, G. V., Ranft, E. O., 2019, Cathodic Protection System Design Framework, SAUPEC/RobMech/PRASA Conference Bloemfontein, South Africa, January 28-30.

DNVGL-RP-B401, 2017, Cathodic Protection Design, Edition June 2017.

Shreir, L. L., Jarman, R. A., Burstein, G. T., 1993, Corrosion - Metal/Environment Reactions vol.1 3rd Edition, Butterworth-Heinemann, Woburn.

Bahadori, A., 2014, Cathodic Corrosion Protection System 1st Edition. Gulf Professional Publishing, NSW, Australia.

Dwight H. B., 1936, Calculation of Resistances To Ground. Electrical Engineering, December 1936, Page 1319-1329.

NACE, 2008, CP3 Cathodic Protection Technologist Course Manual, NACE Standards, Houston.

Smith, S.N.,1992, Analysis of Cathodic Protection on an Underprotected Offshore Pipeline, NACE Annual Conference and Corrosion Show, Paper No.429, NACE, Texas.

Funahashi, M., Wu, H., 2013, What you need to know about MMO coated metal anodes, NACE Corrosion 2013, Paper no. 2107.

Shreir, L. L., Jarman, R. A., Burstein, G. T., 2000, Corrosion - Corrosion Control, Vol.2, Ed. 3, Woburn, Butterworth-Heinemann.

Baete, C., Purcar, M., Bortles,B., Van Den Bossche, B., Dewilde, J-M. (2012) CP System Validation of Offshore Structure Through Modelling, NACE International CORROSION 2012, Paper 0001657 Utah USA 11-15 March 2012.

Stutzmann, J., 2017, Cathodic Corrosion Protection in the Context of Lifetime Extension of Monopile-based Offshore Wind Turbines. Thesis, Department of Materials and Manufacturing Technology, Chalmers University of Technology, Gothenburg, Sweden.

Meillier, A., Court, H., Park, S., 2003, A Review of Galvanic Anode Cathodic Protection Design Procedure, Corrosion Control Services Limited, Stafford Park, Telford, UK.

Shreir, L. L. (1990). Design and Operational Guidance on Cathodic Protection of Offshore Structures, Subsea Installations and Pipelines, London: MTD Ltd Publication. 